\title{
Effects of prawn stocking density and feeding management on rice-prawn culture
}

\author{
Marcello Villar Boock ${ }^{\mathrm{a}, *}$, Helcio Luis de Almeida Marques ${ }^{\mathrm{a}}$, Margarete Mallasen ${ }^{\mathrm{b}, 1}$, Helenice Pereira Barros ${ }^{\mathrm{b}}$, \\ Patrícia Moraes-Valenti ${ }^{\mathrm{c}}$, Wagner C. Valenti ${ }^{\mathrm{d}}$ \\ a UPD Pirassununga, Pólo APTA Centro Leste Paulista, Agência Paulista de Tecnologia dos Agronegócios - Secretaria de Agricultura do Estado de São Paulo, Brasil, Av. Virgilio Baggio 85, \\ 13641-004 Pirassununga, SP, Brazil \\ b Centro APTA do Pescado Continental, Instituto de Pesca, Agência Paulista de Tecnologia dos Agronegócios - Secretaria de Agricultura do Estado de São Paulo, Brasil, PO Box 1052, \\ 15025-970 São José do Rio Preto, SP, Brazil \\ c Universidade de Santo Amaro, UNISA and CAUNESP, Rod. Paulo Donato Castellane s/n, 14884-900 Jaboticabal, SP, Brazil \\ ' São Paulo State University - UNESP, Biosciences Institute and CAUNESP, CNPq, Praça Infante Dom Henrique s/n, 11330-900 São Vicente, SP, Brazil
}

\section{A R T I C L E I N F O}

\section{Article history:}

Received 18 February 2015

Received in revised form 5 October 2015

Accepted 6 October 2015

Available online 13 October 2015

\section{Keywords:}

Integrated system

Macrobrachium rosenbergii

Sustainable

Economically feasible

\begin{abstract}
A B S T R A C T
The effects of prawn (Macrobrachium rosenbergii) stocking density and the use of commercial diet on rice-prawn culture were evaluated. The experimental design was completely randomized in a $2 \times 2$ factorial, with a control (rice monoculture, RM) and four replicates for each treatment. The treatments were: 2 prawns $\mathrm{m}^{-2}$ without feed (2W), 2 prawns $\mathrm{m}^{-2}$ with feed (2F), 5 prawns $\mathrm{m}^{-2}$ without feed ( $\left.5 \mathrm{~W}\right)$ and 5 prawns $\mathrm{m}^{-2}$ with feed (5F). Mean survival varied from $17.2 \pm 9.3 \%(5 \mathrm{~F})$ to $39.2 \pm 14.9 \%(2 \mathrm{~F})$, and mean weight from $20.3 \pm 2.2 \mathrm{~g}(2 \mathrm{~W})$ to $25.7 \pm$ $5.85 \mathrm{~g}$ (2F). Prawn productivity ranged between $118 \pm 58 \mathrm{~kg} \mathrm{ha}^{-1}(2 \mathrm{~W})$ and $224 \pm 46 \mathrm{~kg} \mathrm{ha}^{-1}$ (5W). No significant interactions were observed between feeding management and densities. Survival rate was significantly higher $(P<0.05)$ for the 2 prawn $\mathrm{m}^{-2}$ density while the other variables did not vary significantly among treatments. Rice yields were not statistically different among treatments and varied from $4608 \pm 1225 \mathrm{~kg} \mathrm{ha}^{-1}$ (2F) and $5620 \pm 1202 \mathrm{~kg} \mathrm{ha}^{-1}(\mathrm{RM})$. The results indicate that the rice-prawn system is technically feasible and does not need the addition of commercial diet. Economic analysis showed that stoking 5 prawns $\mathrm{m}^{-2}$ was not profitable. Total production costs and gross revenue were US\$ 1337.84 and US\$ 1182.07 for rice monoculture and US $\$ 2655.60$ and US\$2738.70 for the rice-prawn system ( 2 prawns $\mathrm{m}^{-2}$; without feed), respectively. Therefore, the integrated rice-prawn system is a suitable alternative to make rice production economically feasible on small farms without government subsidies.
\end{abstract}

Statement of relevance:

New finds to the international literature, such as the synergic effect of stocking density and commercial feed supply in simultaneous rice-prawn system assessed by a technical and economic perspective; discussion about carrying capacity of paddy fields, in simultaneous system; natural feed is not a major limiting factor for stocking densities up to 5 prawns $\mathrm{m}^{-2}$ as presumed in other studies.

@ 2015 Elsevier B.V. All rights reserved.

\section{Introduction}

Increasing food production should not only consider the intensification of productive practices, but should also guarantee the sustainable use of natural resources (FAO, 2013a). The focus should be on technology development and management that increase the productivity

\footnotetext{
* Corresponding author at: Rua Virgílio Baggio 85, 13641-004, Pirassununga, SP, Brazil E-mail addresses: mvboock@yahoo.com.br (M.V. Boock), helcio@pesca.sp.gov.br (H.L.A. Marques), helenicebarros@pesca.sp.gov.br (H.P. Barros), moraesvalenti@gmail.com (P. Moraes-Valenti), valenti@clp.unesp.br (W.C. Valenti). 1 In memoriam
}

of low performance systems, reducing the negative impacts while strengthening the positive impacts (FAO, 2011). In this sense, integrated systems (such as rice-prawn culture) that vertically expand production by integrating compatible agricultural products, increasing productivity and reducing environmental impact, are more effective (FAO, 2013a).

Rice is a staple food for many people around the world. It ranks as the second most produced and worldwide consumed cereal (FAO, 2013b). In 2010, world consumption "per capita” was $53.2 \mathrm{~kg}$ of rice, according to FAO estimates. In Brazil, consumption "per capita" was estimated at $34.6 \mathrm{~kg}_{\text {year }}{ }^{-1}$ in 2009 (FAO, 2013b). Despite its importance in food production, rice culture is not often profitable in the long term, which leads the governments to subsidize rice production to ensure food security. 
The integrated production of freshwater prawns with rice (Oryza sativae) has been performed in Asia with good results (Zimmermann et al., 2010). This integrated system is practiced in Bangladesh (Williams et al., 2004; Kunda et al., 2008; Amin and Salauddin, 2008; Nahar, 2010; Ahmed et al., 2010, 2013), India (Kurup and Ranjeet, 2002; Mishra and Mohanty, 2004; Mohanty et al., 2004, 2009; Mohanty, 2010), Thailand (Giap et al., 2005) and Vietnam (Duong, 2001; Hung, 2001; Lan et al., 2006; Phuong et al., 2006). In Brazil, this system has been neglected, despite the great potential represented by thousands of hectares of flooded rice fields.

The rice-prawn integrated culture can be characterized as a multispatial system that uses soil and water more efficiently resulting in higher rice production (Giap et al., 2005; Amin and Salauddin, 2008; Mohanty et al., 2010) and income, especially when Macrobrachium rosenbergii is used due to its high market value (Giap et al., 2005; Lan et al., 2006; Ahmed et al., 2010, 2013). Such systems optimize the use of natural resources, facilities and labor, generating employment opportunities, both within agriculture and associated supply chains, besides harboring a rich biodiversity ecosystem (Ahmed et al., 2010, 2013). All these factors tend to make these systems more sustainable in economic and environmental aspects; however, it is necessary to adapt the technology aimed at profitable results.

Paddies are environments rich in natural food and shelter for the prawns. Conversely, the low depth of the water column limits the available space and subjects the prawns to predators and a large variation of water quality parameters. Therefore, the optimum prawn stocking density supported by the system should be determined. Commercial diets can significantly increase the stoking density and the production of freshwater prawns (Valenti et al., 2010). Nevertheless, commercial diets are expensive in most countries and its use may not be costeffective. In Southeast Asia, some authors have reported that M. rosenbergii production has increased by using artificial diet and (or) animal or vegetable by-products (Giap et al., 2005; Phuong et al., 2006; Mohanty, 2010). However, none of these studies analyzed the synergistic effect of stocking density and feed management when prawns and rice are farmed together at the same time in paddies (simultaneous system). Therefore, further studies are required to assess the carrying capacity of the rice-prawn farm simultaneous systems and the economic feasibility of using commercial diet. In the present study, we analyze the effect of increasing stocking density and supplying commercial diet on the productivity and economic feasibility of $M$. rosenbergii and $O$. sativa simultaneous integrated culture. In addition, we tested the hypothesis that the integrated rice-prawn system makes rice production economically feasible in Southeast Brazil, where rice culture alternate periods of economic gains and losses.

\section{Material and methods}

\subsection{Experimental site and facilities}

The experiment was carried out in a rice culture area, at APTA Research Center, in Mococa, SP $\left(21^{\circ} 28^{\prime} \mathrm{S}, 47^{\circ} 01^{\prime} \mathrm{W}\right)$, from December 2009 to April 2010. An experimental rice field was divided into 20 plots of $30 \mathrm{~m}^{2}$ each (paddies), in which the water level was kept at approximately $35 \mathrm{~cm}$ deep. Harvesting canals (trenches), approximately $50 \mathrm{~cm}$ deep, were excavated in all paddies, near the water outlet. The trench area represented $17 \%$ of the total area.

A filter, composed of a sequence of steel screens set in decreasing order of mesh aperture, was installed in the water supply canal (inlet canal) to minimize the entry of plant debris and aquatic animals. The water was equally distributed to the plots. The inlet and outlet canals had gates that allowed regulating the level and flow independently on each plot. Screens were placed at the outputs of each paddy to prevent the escape of prawns or invasion of aquatic predators.

The experiment was conducted according to a completely randomized $2 \times 2$ factorial design, with one control and four treatments, with four replications. The factors tested were the density of prawns ( 2 and 5 prawns $\mathrm{m}^{-2}$ ) and the use of commercial diet (without and with feed supply). The treatments were: rice monoculture (RM; control); 2 prawns $\mathrm{m}^{-2}$ without feed ( $\left.2 \mathrm{~W}\right) ; 2$ prawns $\mathrm{m}^{-2}$ with feed (2F); 5 prawns $\mathrm{m}^{-2}$ without feed ( $5 \mathrm{~W}$ ) and 5 prawns $\mathrm{m}^{-2}$ with feed (5F).

The IAC 106 rice variety was used due to its longer cycle and greater resistance to water level rising, characteristics necessary for rice-prawn culture. Pre-germinated seeds were planted in seedling beds and rice plants were irrigated continuously for 21 days, until they reached the appropriate size $(8-10 \mathrm{~cm})$ to be transplanted to the paddies in $20 \mathrm{~cm}$ spaced rows. Soil preparation consisted of applying lime (1000 $\mathrm{kg} \mathrm{ha}^{-1}$ ) and 8-28-16 NPK fertilizer ( $360 \mathrm{~kg} \mathrm{ha}^{-1}$ ). Top dressing with urea ( $65 \mathrm{~kg}$ nitrogen ha ${ }^{-1}$ ) was conducted 15 days after transplantation and repeated a fortnight later. No pesticides were used and weeds were controlled by manual weeding and hoeing.

$M$. rosenbergii juveniles, 45 days old with a length of $2.5 \pm 0.4 \mathrm{~cm}$ and weighing $0.13 \pm 0.07 \mathrm{~g}$ (mean $\pm \mathrm{SD}$ ), were stocked in paddies 40 days after rice transplanting, when the plants were approximately $40 \mathrm{~cm}$ height.

\subsection{Water variables}

Dissolved oxygen, oxygen saturation percentage and $\mathrm{pH}$ of the water were monitored daily in all experimental paddies with an oxygen meter and a pH meter (Hanna Instruments). The maximum and minimum temperatures were also recorded daily using maximum and minimum thermometers (Incoterm) that were placed randomly in the trench of three paddies. Biweekly water samples were collected from the inlet and outlet canals and from all paddies (water collected in the trench) to determine total ammonia nitrogen $\left(\mathrm{N}-\mathrm{NH}_{3}+\mathrm{N}-\mathrm{NH}_{4}^{+}\right)$, N-nitrite $\left(\mathrm{N}-\mathrm{NO}_{2}^{-}\right), \mathrm{N}$-nitrate $\left(\mathrm{N}-\mathrm{NO}_{3}^{-}\right)$, total nitrogen $(\mathrm{N})$ and total phosphorus (P) according to APHA (2005).

\subsection{Feeding, biometrics and harvesting}

D'Abramo and Sheen (1994) and Tidwell et al. (1997) have demonstrated that no feeding is required in monoculture ponds until the biomass density of a pond population has reached $18-25 \mathrm{~g} \mathrm{~m}^{-2}$. Thus, no feed was supplied during the first month of culture. From the second month onward, commercial diet produced for penaeid shrimp, containing $35 \%$ crude protein was supplied to prawns of $2 \mathrm{~F}$ and $5 \mathrm{~F}$ treatments, once a day. The feed was thrown in trenches and among rice rows so that most of the prawn had access to it. The feeding rate was adjusted monthly at decreasing daily rates of 5,3 and 1\% prawn biomass, estimated for each treatment after biometry. After partial draining of each paddy, prawns (5-10\% of the population), captured using dip nets, were measured and weighed on a digital scale with $0.01 \mathrm{~g}$ precision.

The rice was harvested 110 days after transplant. The rice samples were sun dried until 13\% moisture and then weighed. The area occupied by harvesting canals in rice-prawn plots (17\% of total of the paddies) was not discounted in the RM treatment for calculating the yield per hectare.

After 122 days of stocking, the paddies were completely drained off; the prawns were harvested among the rice rows with dip nets and with a bigger net placed inside the harvesting canals before the draining operation. All prawns were killed in ice water (about $0{ }^{\circ} \mathrm{C}$ ), counted, and subsequently weighed and measured individually. Survival (\%), mean final weight $(\mathrm{g})$ and productivity $\left(\mathrm{kg} \mathrm{ha}^{-1}\right)$ were calculated.

To determine the social structure, the prawns were separated by sex and identified according to the male morphotypes: small male - SM; orange claw - OC; and blue claw - BC (Kuris et al., 1987). Furthermore, classes of female sexual maturation were determined by macroscopic observation of the size and coloration of the ovary and classified as follows: immature females - IF (whitish ovary); maturing females MF1 (ovarian orange); mature females - MF2 (orange ovary, occupying 
almost the entire coelomic cavity) and ovigerous females - FO (presence of eggs attached to the pleopods).

\subsection{Statistical analysis}

Limnological data, prawn survival, final weight and productivity as well as rice productivity data were subjected to Kolmogorov and Smirnov and Bartlett tests to check normality and homoscedasticity, respectively. Once these requirements were fulfilled, the mean values were subjected to two-way analysis of variance (repeated measures ANOVA, for limnological data) followed by Tukey's test (Zar, 1999). The paired $t$-test (Zar, 1999) was used to compare the variables phosphorus, total nitrogen and total ammonia from the water supply and effluent. The values expressed in percentages were arcsine square root transformed before analysis; however, for better understanding the original data are presented. The statistical analyses were performed using the SAS software. The significant difference was considered at $P<0.05$.

\subsection{Economic analysis}

The economic evaluation considered 1 ha of already operating flooded rice monoculture, adapted for the integrated rice-prawn culture. The partial budget analysis (Shang, 1990) was performed because it was supposed that there was a partial change in farm facilities and operation due to the introduction of the prawns in the rice paddies. No significant difference in production was observed between fed and unfed treatments, thus, we only performed the economic analysis for unfed treatments.

The total cost (TC) was divided into variable and fixed costs. The total variable costs included rice seed (US\$ $0.46 \mathrm{~kg}^{-1}$ ), 45 -day old M. rosenbergii juveniles (US\$ 35.06 per 1000 units) and other minor costs, such as tools, limestone, fertilizer, fuel expenses, ice, plastic bags for prawn packaging and hired labor for harvesting the prawns. Fixed costs included taxes and fees (US\$ 62.73), depreciation (harvesting canals, filters and equipment), interest (6.9\% year ${ }^{-1}$ ) and maintenance costs ( $2 \%$ of total value of equipment and facilities per year). The cost of the rice field construction was not taken on account as an initial investment, because we considered that rice farming was already operating; only the capital expenditures related to the adjustments made in the paddies to implement the prawn-rice system, such as the construction of both harvesting canals $50 \mathrm{~cm}$ deep (US\$ $4649.45 \mathrm{ha}^{-1}$ ) and the mechanical filter (US\$29.52) were accounted. The average productions obtained in this study were used to calculate the revenue. The selling price of rice is estimated at US\$ 10.52 per bag ( $50 \mathrm{~kg}$ ) while prawns at US\$ 10.33 per $\mathrm{kg}$.

Initially, a partial budget analysis (Shang, 1990) was performed to assess which of the two densities studied ( 2 and 5 prawns $\mathrm{m}^{-2}$ ) was more economically feasible. In this analysis, the costs in adapting the paddies were considered as investment and, as fixed costs, the

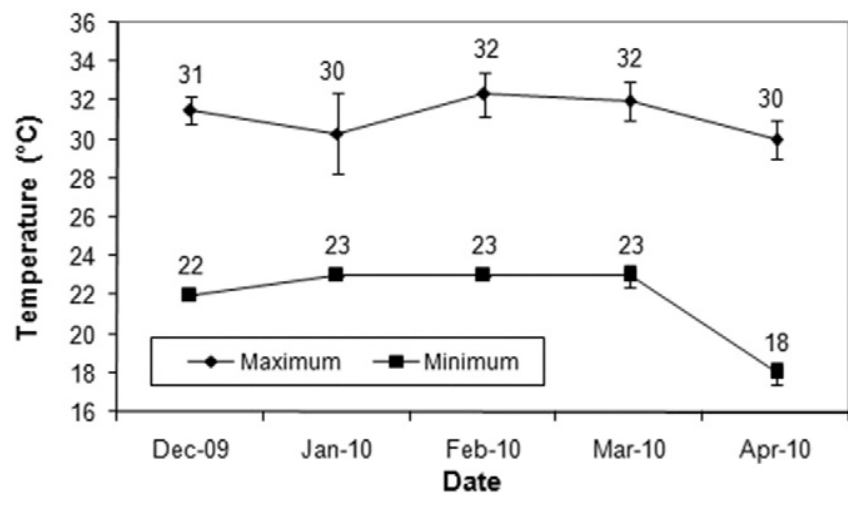

Fig. 1. Monthly maximum and minimum absolute temperatures (with a higher maximum and lower minimum that occurred in the same month) recorded during the period.

depreciation and interest. Only the operating expenses and revenues arising from the introduction of prawns in the rice-prawn system were computed, not accounting for the costs and revenues related to rice.

Subsequently, a comparative partial budget analysis was carried out between rice monoculture and the integrated system using the average production obtained from the prawn density with best results in the former analysis ( 2 prawns $\mathrm{m}^{-2}$ ). This analysis took into account all operating expenses with prawns described above plus the operation expenses with the rice and the investments with the implementation of the integrated system (adaptation of paddies and filter construction). The revenues from the production of rice and prawn were considered.

The following indicators of financial feasibility were calculated according to Shang (1990) and Jolly and Clonts (1993): net present value (NPV), internal rate of return (IRR), payback period (PP) and benefit/cost ratio (BCR). The minimum attractive rate of return (MARR) and the discount rate were both set at $6.9 \%$ per year.

All financial values were converted from Real to U.S. Dollar, considering the quotation done in the Central Bank of Brazil (http://www4. bcb.gov.br/pec/taxas/batch/taxas.asp?id=txdolar) at February 2015.

\section{Results}

\subsection{Water parameters}

The mean values of the limnological parameters of the effluent water from the paddies were similar between treatments. Only the nitrate mean values were higher $(P<0.05)$ in 5 prawns $\mathrm{m}^{-2}$ density treatments than in the control (Table 1 ). Absolute minimum and maximum temperatures varied greatly between 18 and $33^{\circ} \mathrm{C}$ obtained in April and February 2010, respectively. The greatest difference between these temperatures in the same month was $13^{\circ} \mathrm{C}$, in Apr/2010 (Fig. 1). Concentrations of ammonia, nitrite and nitrate in water

Table 1

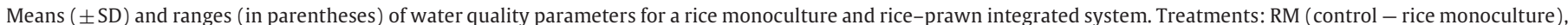
$2 \mathrm{~W}$ ( 2 prawn $\mathrm{m}^{-2}$ without feed); $2 \mathrm{~F}$ ( 2 prawn $\mathrm{m}^{-2}$ with feed); $5 \mathrm{~W}$ ( 5 prawn $\mathrm{m}^{-2}$ without feed) and $5 \mathrm{~F}$ ( $5 \mathrm{prawn}^{-2}$ with feed).

\begin{tabular}{|c|c|c|c|c|c|}
\hline \multirow[t]{2}{*}{ Parameters } & \multicolumn{5}{|l|}{ Treatments } \\
\hline & RM & $2 \mathrm{~W}$ & $2 \mathrm{~F}$ & $5 \mathrm{~W}$ & $5 \mathrm{~F}$ \\
\hline $\begin{array}{l}\text { Dissolved oxygen } \\
\quad\left(\mathrm{mg} \mathrm{L}^{-1}\right)\end{array}$ & $3.7 \pm 0.4(2.2-5.3)$ & $3.9 \pm 0.6(2.2-5.4)$ & $3.6 \pm 0.6(2.2-5.2)$ & $3.6 \pm 0.5(2.1-4.1)$ & $4.1 \pm 0.5(3.3-4.6)$ \\
\hline $\mathrm{pH}$ & $7.0 \pm 0.2(6.4-7.4)$ & $7.0 \pm 0.2(6.5-7.3)$ & $6.9 \pm 0.2(6.5-7.2)$ & $6.9 \pm 0.2(6.5-7.3)$ & $7.0 \pm 0.3(6.3-7.3)$ \\
\hline $\begin{array}{l}\mathrm{N}-\mathrm{NH}_{3}+\mathrm{N}-\mathrm{NH}_{4}^{+} \\
\quad\left(\mu \mathrm{g} \mathrm{L}^{-1}\right)\end{array}$ & $55.6 \pm 33.6(20.6-108.9)$ & $52.5 \pm 28.9(34.3-103.4)$ & $52.5 \pm 24.1(35.6-92.3)$ & $59.9 \pm 15.3(37.8-76.7)$ & $50.2 \pm 24.7(33.1-92.5)$ \\
\hline $\mathrm{N}-\mathrm{NO}_{2}^{-}\left(\mu \mathrm{g} \mathrm{L}^{-1}\right)$ & $19.0 \pm 10.9 \mathrm{~b}(4.7-30.3)$ & $20.9 \pm 13.8 \mathrm{ab}(5.2-36.3)$ & $22.1 \pm 14.4 \mathrm{ab}(5.5-36.6)$ & $23.8 \pm 14.6$ a $(5.2-36.5)$ & $23.5 \pm 14.6 \mathrm{a}(4.8-35.9)$ \\
\hline $\mathrm{N}-\mathrm{NO}_{3}^{-}\left(\mu \mathrm{g} \mathrm{L}^{-1}\right)$ & $78.0 \pm 24.5(51.6-104.1)$ & $74.8 \pm 40.6(25.4-133.3)$ & $78.4 \pm 46.1(16.8-126.9)$ & $91.4 \pm 54.4(21.1-160.4)$ & $71.8 \pm 52.2(9.6-144.5)$ \\
\hline$P$ total $\left(\mu \mathrm{g} \mathrm{L}^{-1}\right)$ & $105.2 \pm 4.7(100.6-111.7)$ & $192.2 \pm 199.8(58.1-488.3)$ & $185.2 \pm 198.7(55.0-480.8)$ & $261.4 \pm 222.3(68.5-527.0)$ & $208.9 \pm 208.8(80.0-520.0)$ \\
\hline $\mathrm{N}$ total $\left(\mu \mathrm{g} \mathrm{L}^{-1}\right)$ & $149.3 \pm 75.9(66.2-264.4)$ & $130.7 \pm 33.3(40.6-219.7)$ & $139.6 \pm 56.0(32.4-263.5)$ & $147.2 \pm 40.8(46.3-256.9)$ & $140.7 \pm 59.7(14.4-280.4)$ \\
\hline
\end{tabular}

Different letters in the line indicate significant differences by Tukey's test $(P<0.05)$. 

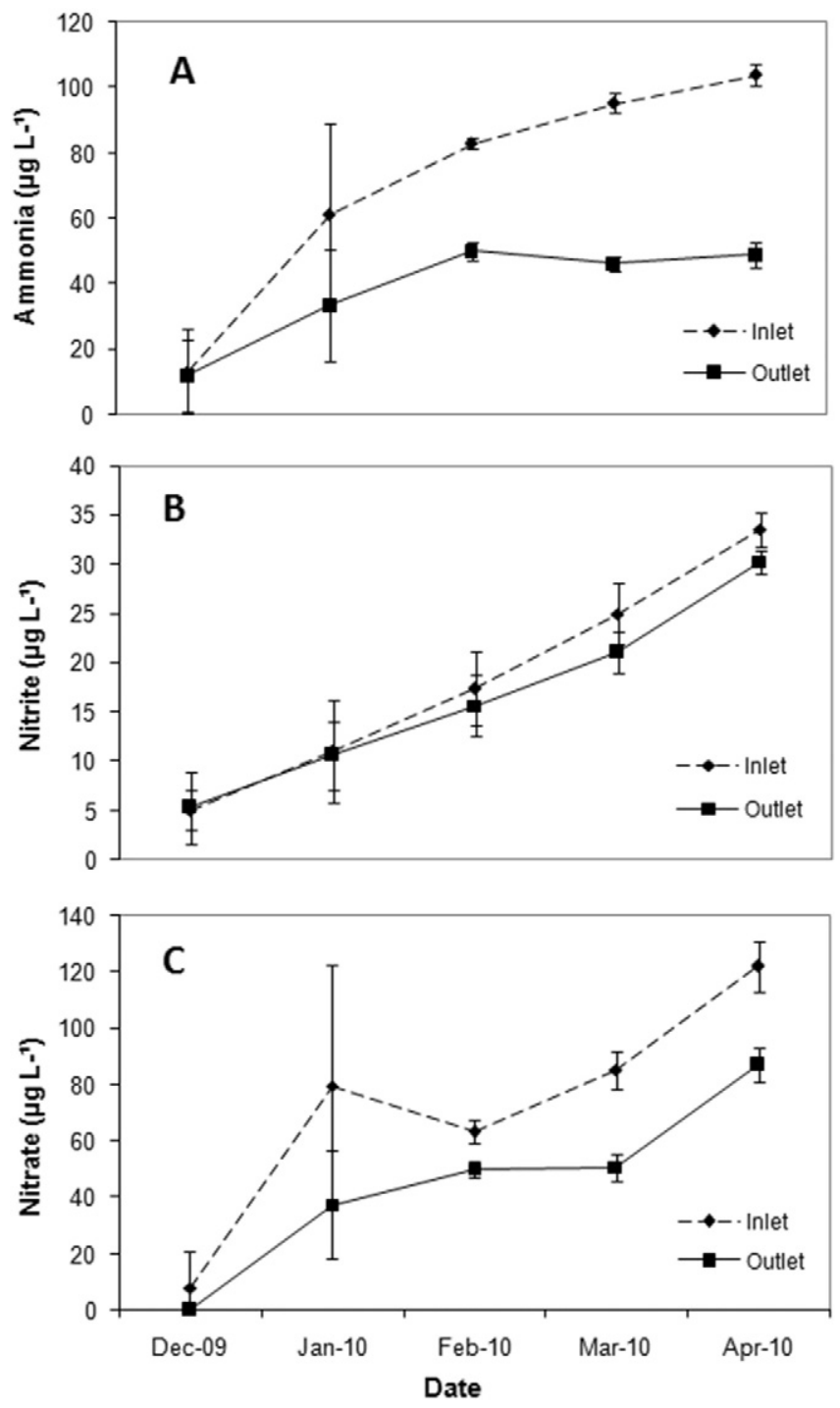

Fig. 2. Monthly concentrations (mean $\pm \mathrm{SD}$ ) of the ammonia (A), nitrite (B) and nitrate (C), registered in the inlet and outlet canals.

increased during the experimental period in all the treatments while total nitrogen and total phosphorus concentrations varied along the period.

The mean values of ammonia and nitrate in the outlet water were significantly lower $(P<0.05)$ than those of the inlet water while the values were higher at the end of the culture (Fig. $2 \mathrm{~A}$ and $\mathrm{C}$ ). On the other hand, total phosphorus level was higher in the outlet canal compared to the inlet, except in Feb/2010, although no statistical difference was obtained (Fig. 3A and B).

\subsection{Rice and prawn production}

No significant interactions were observed between feeding and density. Likewise, there were no significant differences between treatments for weight and prawn productivity, but survival was significantly higher $(P<0.05)$ for the $2 \mathrm{~m}^{-2}$ density. Rice production was not significantly affected either by the presence of prawns or the tested factors (Table 2).

The distribution of prawns in weight class at harvest was almost similar in all treatments. Generally, 90\% of prawns attained a weight above $15 \mathrm{~g}$, which is the commercial size in Brazil (Fig. 4).
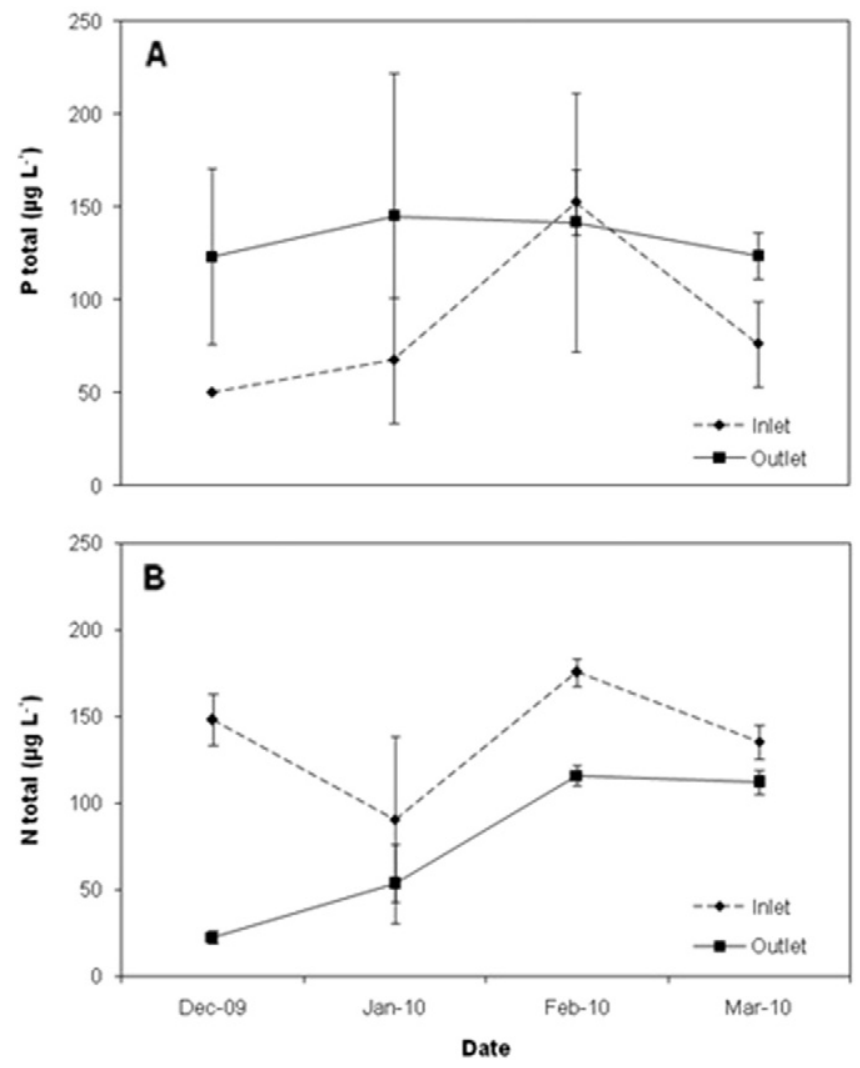

Fig. 3. Monthly concentrations (mean $\pm \mathrm{SD}$ ) for the total phosphorus $(\mathrm{A})$ and total nitrogen (B) registered in inlet and outlet canals.

The male and female population structures observed at harvesting were similar among treatments. There was a predominance of the small male (SM) morphotype and immature females (IF) (Fig. 5).

Table 2

Effect of density and commercial diet on prawn survival, weight, prawn and rice productivity in the integrated system $(\mathrm{n}=4)$. Treatments: RM (control - rice monoculture); $2 \mathrm{~W}$ ( 2 prawns $\mathrm{m}^{-2}$ without feed); $2 \mathrm{~F}$ ( 2 prawns $\mathrm{m}^{-2}$ with feed) and $5 \mathrm{~W}$ ( 5 prawns $\mathrm{m}^{-2}$ without feed); $5 \mathrm{~F}$ ( 5 prawns $\mathrm{m}^{-2}$ with feed).

\begin{tabular}{|c|c|c|c|c|}
\hline Treatments & $\begin{array}{l}\text { Survival } \\
(\%)\end{array}$ & $\begin{array}{l}\text { Prawn } \\
\text { average } \\
\text { weight (g) }\end{array}$ & $\begin{array}{l}\text { Prawn } \\
\text { productivity } \\
\left(\mathrm{kg} \mathrm{ha}^{-1}\right)\end{array}$ & $\begin{array}{l}\text { Rice productivity } \\
\left(\mathrm{kg} \mathrm{ha}^{-1}\right)\end{array}$ \\
\hline RM & - & - & - & $5620.0 \pm 1201.6$ \\
\hline $2 W$ & $29.6 \pm 13.6$ & $20.3 \pm 2.2$ & $117.6 \pm 57.9$ & $5196.8 \pm 299.2$ \\
\hline $2 \mathrm{~F}$ & $39.2 \pm 14.9$ & $25.7 \pm 5.9$ & $183.7 \pm 32.4$ & $4607.7 \pm 1225.2$ \\
\hline $5 \mathrm{~W}$ & $22.2 \pm 5.8$ & $21.1 \pm 1.7$ & $224.0 \pm 46.1$ & $4610.7 \pm 619.5$ \\
\hline $5 \mathrm{~F}$ & $17.2 \pm 9.3$ & $20.3 \pm 3.5$ & $176.1 \pm 98.0$ & $4719.6 \pm 636.3$ \\
\hline \multicolumn{5}{|c|}{ Grouped averages for densities } \\
\hline $2 \mathrm{~m}^{-2}$ & $33.7 \mathrm{a}$ & 21.7 & 155.0 & 4902.3 \\
\hline $5 \mathrm{~m}^{-2}$ & $19.0 \mathrm{~b}$ & 20.7 & 205.9 & 4665.2 \\
\hline \multicolumn{5}{|c|}{ Grouped averages for feeding } \\
\hline Without feeding & 30.2 & 20.6 & 175.77 & 4903.8 \\
\hline With feeding & 31.2 & 21.7 & 185.13 & 4663.7 \\
\hline $\begin{array}{l}\text { Grouped averages } \\
\text { for the control } \\
\text { (only rice) }\end{array}$ & - & - & - & 4663.7 \\
\hline \multicolumn{5}{|l|}{ ANOVA } \\
\hline Density & * & ns & ns & ns \\
\hline Feeding & ns & ns & ns & ns \\
\hline Density $\times$ feeding & ns & ns & ns & ns \\
\hline Control $\times$ factor & ns & ns & ns & ns \\
\hline
\end{tabular}

Means followed by different superscript letters in the column indicate significant difference (ANOVA bi factorial; ns = non-significant).

* $P<0.05$. 

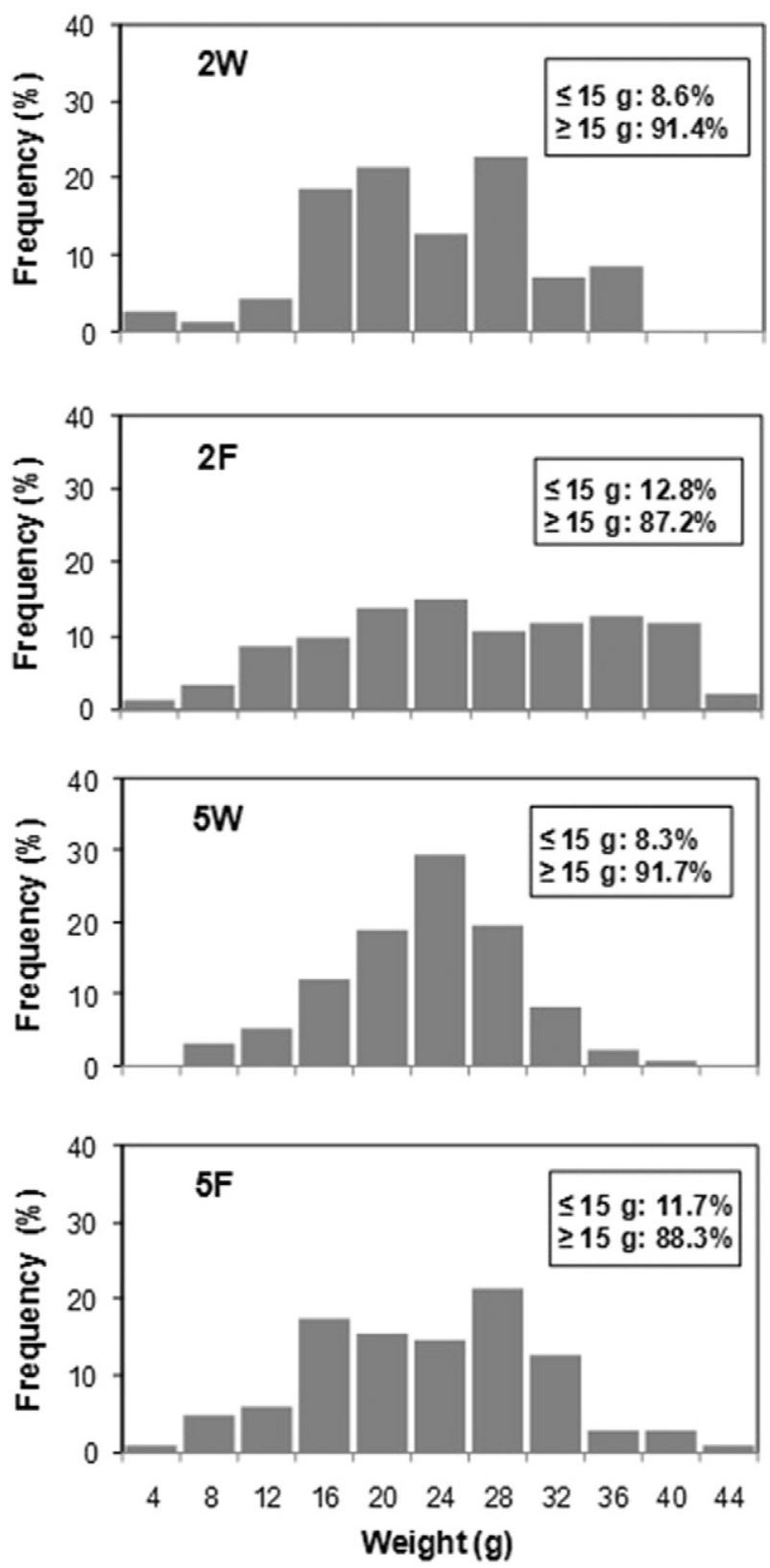

Fig. 4. $M$. rosenbergii weight classes for the integrated system. Treatments: $2 \mathrm{~W}$ ( 2 prawns $\mathrm{m}^{-2}$ without feed); $2 \mathrm{~F}$ ( 2 prawns $\mathrm{m}^{-2}$ with feed); $5 \mathrm{~W}$ ( 5 prawns $\mathrm{m}^{-2}$ without feed); $5 \mathrm{~F}$ (5 prawns $\mathrm{m}^{-2}$ with feed).

\subsection{Economic analysis}

The partial budget analysis showed that the $2 \mathrm{~m}^{-2}$ density treatment was profitable, whereas $5 \mathrm{~m}^{-2}$ treatment led to a loss of money (Table 3). The purchase of $M$. rosenbergii juveniles represented 67.7 and $79.2 \%$ of the total cost for $2 \mathrm{~m}^{-2}$ and $5 \mathrm{~m}^{-2}$ prawn densities, respectively. Total production costs at the density of 5 prawns $\mathrm{m}^{-2}$ were almost double to those recorded for 2 prawns $\mathrm{m}^{-2}$. The gross revenue, in turn, did not differ in the same proportion (Table 3). Since the density of 5 prawns $\mathrm{m}^{-2}$ resulted in loss, the financial feasibility indicators were not calculated.

The gross revenue (GR) in the rice-prawn system (US\$2738.70) was almost 2.5 times greater than in rice monoculture (US\$ 1182.07). The rice monoculture (RM - control) is economically unfeasible for the conditions herein, affording a loss of US\$ 155.77 by cycle (Table 4). The integrated system was economically feasible providing
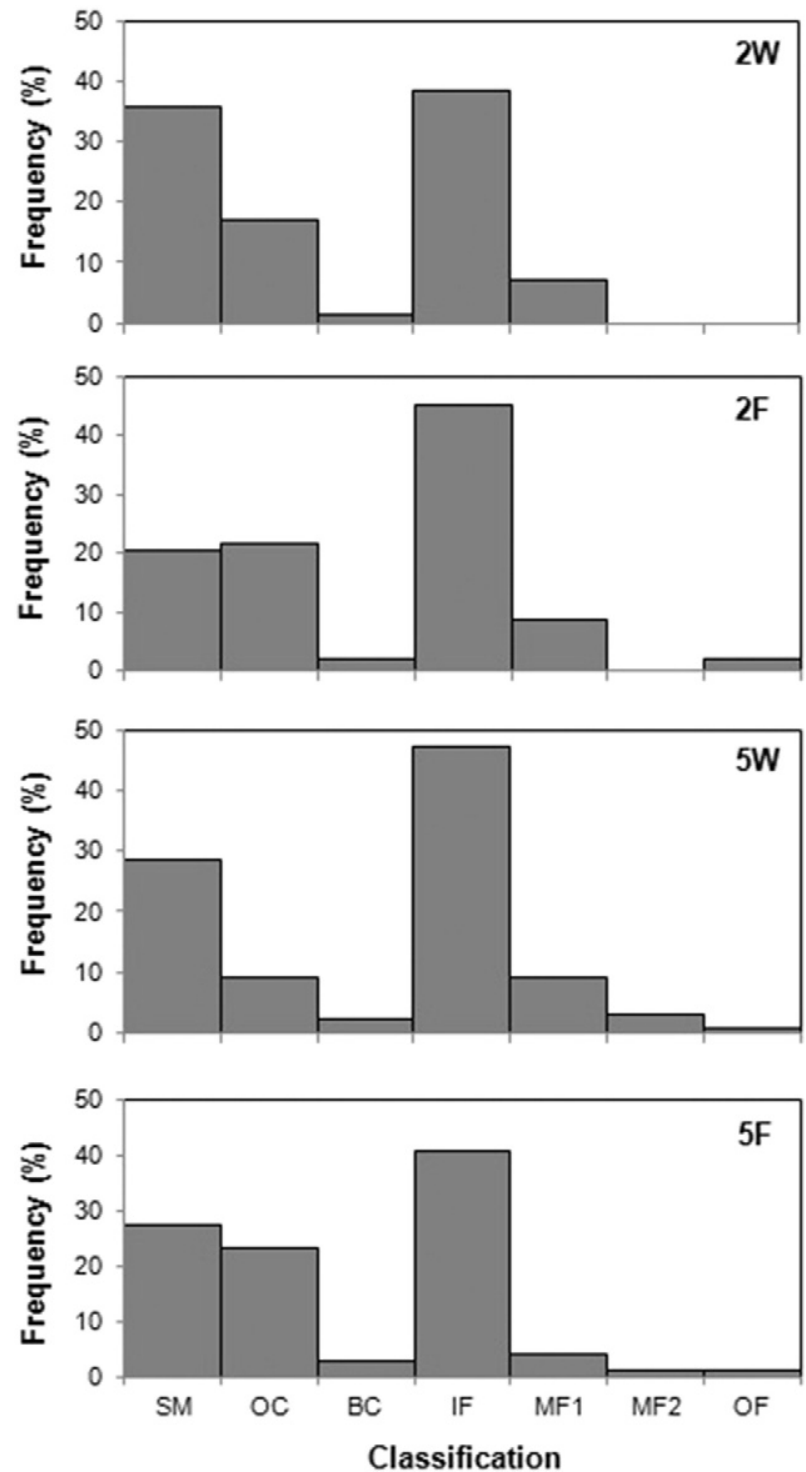

Fig. 5. Male and female population structure observed for $M$. rosenbergii reared in riceprawn integrated systems for the treatments: $2 \mathrm{~W}\left(2\right.$ prawns $\mathrm{m}^{-2}$ without feed); $2 \mathrm{~F}$ ( 2 prawns $\mathrm{m}^{-2}$ with feed); $5 \mathrm{~W}$ ( 5 prawns $\mathrm{m}^{-2}$ without feed) and $5 \mathrm{~F}$ ( 5 prawns $\mathrm{m}^{-2}$ with feed). SM - small male; OC - orange claw; BC - blue claw; IF - immature females; MF1 - maturing females; MF2 - mature females, OF - ovigerous females.

a profit of US\$ 83.10 by cycle and it could still be higher, if there is an increase in rice prices in a future scenario; the IRR (6.4\%) was close to the MARR (6.9\%), while the B/C was US\$ 0.91 and PP was within the project horizon (15.1 years).

\section{Discussion}

Data showed that the prawn density and the use of commercial diet did not affect the main water quality and effluent parameters. Besides, these factors did not affect prawn growth and population development or prawn and rice production. Nevertheless, increasing prawn density dramatically impacted economic results, decreasing profitability.

Limnological data in aquaculture ponds generally show high variability (Kimpara et al., 2011), which decreases the power of the main statistical tests to detect significant differences (Sokal and Rohlf, 1995). Some authors have reported that the presence of shrimp and/ or fish promotes further reduction in dissolved oxygen in comparison with rice monoculture, especially at the end of the production cycle, when the biomass is higher (Giap et al., 2005; Frei et al., 2007; 
Table 3

Costs and returns of prawn production in the rice/prawn integrated system at densities of 2 and 5 prawns $\mathrm{m}^{-2}$. Economic indicators (internal rate of return - IRR, net present value $-\mathrm{NPV}$, benefit/cost $-\mathrm{B} / \mathrm{C}$, and payback period $-\mathrm{PP}$ ) are presented only for the 2 prawn $\mathrm{m}^{-2}$ density. Financial values presented in US dollars (US\$1.00 $=\mathrm{R} \$ 2.71$ in Feb. 2015). Calculations based on a module of 1 ha.

\begin{tabular}{|c|c|c|}
\hline Items & 2 prawns $\mathrm{m}^{-2}$ & 5 prawns $\mathrm{m}^{-2}$ \\
\hline \multicolumn{3}{|l|}{ A. Costs } \\
\hline Total variable costs & 1035.40 & 2213.16 \\
\hline Total fixed costs & 336.09 & 335.86 \\
\hline Total production costs (TC) & 1371.49 & 2549.02 \\
\hline Average variable costs (US\$ kg-1) & 6.87 & 11.06 \\
\hline Average fixed cost (US\$ $\mathrm{kg}^{-1}$ ) & 2.23 & 1.68 \\
\hline Average total cost (US\$ kg-1) & 9.10 & 12.74 \\
\hline \multicolumn{3}{|l|}{ B. Returns } \\
\hline Gross revenue $(\mathrm{GR})^{\mathrm{a}}$ & 1556.64 & 2066.94 \\
\hline Profit $(G R-T C)^{a}$ & 185.15 & -482.08 \\
\hline \multicolumn{3}{|l|}{ C. Indicators } \\
\hline $\operatorname{IRR}(\%)$ & 13.7 & - \\
\hline NPV (US\$) & 1784.08 & - \\
\hline $\mathrm{B} / \mathrm{C}$ (US\$) & 1.03 & - \\
\hline PP (years) & 6.7 & - \\
\hline
\end{tabular}

a Values calculated based on the selling price of prawn: US\$10.85 $\mathrm{kg}^{-1}$.

Mohanty et al., 2009, 2010). However, the levels of dissolved oxygen in this study which remained almost constant throughout the cultivation in all treatments. Simple techniques such as daily monitoring of oxygen levels, maintaining continuous flow of water in the paddies and using the appropriate stocking densities can also be adopted by producers to maintain adequate dissolved oxygen levels.

Despite that the water temperatures can be considered adequate for the development of $M$. rosenbergii along the trial, the daily changes are higher than in excavated ponds, because the paddies of the integrated systems are shallow. This thermal oscillation due to the shallowness of the water may have decreased prawn survival. According to Lan et al. (2006) and Frei et al. (2007), the high temperatures in the rice fields during mid-afternoon are one the most important factors affecting prawn survival and yield. Therefore, further management strategy studies and adaptation of the structures of rice paddies should be pursued in order to reduce these oscillations, such as increasing paddy depth and covering the harvesting canal.

In integrated production systems, such as rice-prawn culture, water quality is influenced by the chemical, physical and biological characteristics of the aquatic environment while depending also on cultivated plant biomass (rice) (Mohanty et al., 2009). This dynamics may result

Table 4

Costs and returns for rice monoculture and integrated systems $\left(2\right.$ prawn $\left.\mathrm{m}^{-2}\right)$ and economic indicators (internal rate of return - IRR, net present value - NPV, cost benefit $\mathrm{C} / \mathrm{B}$ and payback period - PP) for the integrated system. Indicators calculated based on a 20-year horizon. In the integrated system, we considered all costs and returns for rice and prawns. Financial values presented in US dollars. (US\$ $1.00=\mathrm{R} \$ 2.71$ in Feb. 2015). Calculations based on a module of 1 ha.

\begin{tabular}{lll}
\hline Items & Rice monoculture & Rice-prawn system \\
\hline A. Costs & & \\
Variable total cost & 917.90 & 1899.80 \\
Fixed total cost & 419.94 & 755.80 \\
Total production cost (TC) & 1337.84 & 2655.60 \\
B. Returns & & \\
Gross revenue (GR) & & \\
Profit (GR - TC) & 1182.07 & 2738.70 \\
C. Indicators & -155.77 & 83.10 \\
IRR (\%) & & \\
NPV (US\$) & - & 6.4 \\
B/C (US\$) & - & -189.89 \\
PP (years) & - & 0.91 \\
\hline
\end{tabular}

* Values calculated based on the selling price of US\$ 10.33 per kg of prawn and US\$ 10.52 per $50 \mathrm{~kg}$-bag of rice. in the fluctuation of physical and chemical variables, especially of nutrients ( $\mathrm{N}$ and $\mathrm{P}$ ) as observed in this study. Despite the variability observed in the present experiment, water was maintained in the range suitable for the development of $M$. rosenbergii according Boyd and Zimmermann (2010).

Average $\mathrm{N}^{-\mathrm{NO}_{3}^{-}}$was higher in treatments $5 \mathrm{~W}$ and $5 \mathrm{~F}$ than in $\mathrm{RM}$ (Table 1), suggesting a possible influence of prawn density on input or decomposition of organic matter. The concentration of $\mathrm{N}_{-} \mathrm{NO}_{3}^{-}$was below the values obtained by Keppeler and Valenti (2006) in monoculture of Macrobrachium amazonicum $\left(1239 \pm 1696 \mu \mathrm{g} \mathrm{L}^{-1}\right)$. The mean values of $\mathrm{N}-\mathrm{NH}_{3}+\mathrm{N}-\mathrm{NH}_{4}^{+}$and $\mathrm{N}-\mathrm{NO}_{2}^{-}$were also lower than those observed by the same authors $\left(208 \pm 99 \mu \mathrm{g} \mathrm{L}^{-1}\right.$ and $54 \pm 18 \mu \mathrm{g} \mathrm{L}^{-1}$, respectively). This data indicate that the nitrogen compounds present in the water supply and those produced by prawn culture are absorbed by the rice.

No differences were detected in N-total and P-total variables of water among the rice production in the monoculture and integrated system. Probably, this result may be due to similar levels of inorganic fertilizer inputs in all treatments. Similar results were obtained by Lan et al. (2006); Frei et al. (2007) and Mohanty (2010). The general increase in the nitrogen compound concentration during culture is due to the increase in the concentration of such substances in the inlet water.

Total $\mathrm{P}$ and $\mathrm{N}$ values in this experiment were lower than those obtained by Henares et al. (2011) for a prawn monoculture in Brazil ( $0.67 \mathrm{mg} \mathrm{L}^{-1}$ total nitrogen and $0.235 \mathrm{mg} \mathrm{L}^{-1}$ total phosphorus). Although in this study the concentrations of total phosphorus were higher in the integrated system compared to the rice monoculture, they were still lower than those reported by Boyd and Zimmermann (2010), for M. rosenbergii monocultures in Brazil (from 0.01 to $4.4 \mathrm{mg} \mathrm{L}^{-1}$ ) and Kunda et al., 2008 (from 0.1 to $1.2 \mathrm{mg} \mathrm{L}^{-1}$ ) for a rice-prawn integrated system in Bangladesh.

Lower amounts of nitrogenous compounds in the drainage canal compared to supply are probably due to absorption by the rice plants and periphyton, acting as a wetland. In constructed wetland systems, the main biological processes that regulate the removal of nitrogen and phosphorus in the effluent are the direct absorption by macrophytes, microbial mineralization and transformations such as denitrification and ammonification (USEPA, 2000). According to Forés and Comín (1992), the rice fields can be considered as ecological filters because the outflowing water generally contains less suspended and dissolved material than inflowing waters.

There are two different systems employed in the rice-prawnculture: simultaneous and rotational. In the simultaneous system, the prawns are stocked in the paddies a few days after planting rice and are usually harvested just before the rice. In the rotational system, the prawns are stocked soon after harvest and they benefit from the remnants of rice plants before the new planting. In our experiment, we chose the simultaneous system. The rotational system would be impractical due to the low temperatures observed between May and September in Southern Brazil. In the present experiment, the prawn growth during four months of culture was similar to that one reported by Giap et al. (2005) and Mohanty et al. (2010), who observed average weights between 14.7-23.8 g and $28.8 \mathrm{~g}$, respectively, in a simultaneous system. Conversely, growth was lower than those reported by Lan et al. (2006); Amin and Salauddin (2008) and Kunda et al. (2008), who studied the rotational polyculture systems and reported average weights ranging from 32.2 to $38.1 \mathrm{~g}, 34.7$ to $55.2 \mathrm{~g}$ and 49.8 to $57.3 \mathrm{~g}$, respectively. Probably, the main reason for this low performance is the shorter rearing period of the simultaneous system in comparison to the rotational, which vary from four to eight months.

Prawns stocked at $5 \mathrm{~m}^{-2}$ showed lower survival and the same average final weight of those stocked at $2 \mathrm{~m}^{-2}$. The final density was $0.7-1.0 \mathrm{~m}^{-2}$ in both treatments. It may indicate that the carrying capacity of the system is close to $2 \mathrm{~m}^{-2}$. Feed is not the limiting factor because survival and growth did not increase when commercial diet was 
provided. The competition for shelter, agonistic behavior and predation could explain the lower survival in higher densities. In the 5-density treatment, the competition is certainly higher, thus increasing the possibility of agonistic encounters leading to stress and maybe cannibalism. The low level of water in paddy fields favors the predation by insects, fish, birds and even mammals. Especially at the beginning of the experiment, when rice plants are very small, prawns may compete for the few shelters available and a great number will be exposed to predators in high densities. Further research should be conducted to know the main limiting factors and how to avoid them, allowing for an increase in stocking density and productivity.

The survival rates obtained in the present experiment is low compared to M. rosenbergii monocultures, although they are compatible with the rice-prawn integrated systems described by Kurup and Ranjeet (2002), that who reported survival from $25 \%$ to $38 \%$ in India. The higher survival found at a density of $2 \mathrm{~m}^{-2}$ in the present study indicates that the rice paddies do not support a high stocking density of M. rosenbergii and $5 \mathrm{~m}^{-2}$ probably exceeds the carrying capacity of the system. This hypothesis is supported by similar results obtained by Lan et al. (2006) and Kunda et al. (2008) who studied rice and M. rosenbergii integrated culture and had the best survival ( 49.8 and $57 \%$, respectively) for treatments with a density of 1 prawn $\mathrm{m}^{-2}$. However, Lan et al. (2006) also observed that the best economic results were obtained for the 3 prawn $\mathrm{m}^{-2}$ density, where the prawns were fed with artificial diets and clam meat as supplement. Mohanty et al. (2009) reported a mean survival rate of $32.9 \%$ in the simultaneous system (rice-fish-prawn), meanwhile the survival increased to 56.1\% with the adoption of selective harvesting management.

The water temperature oscillation, predation and escapes are probably the main causes of the low survival of prawns in paddy fields. Some predators, especially fish of the families Characidae (Astyanax altiparanae) and Erythrinidae (Hoplias malabaricus) were observed in all the paddies, which have probably passed through the screens of the filter when they were still juveniles or larvae. On the other hand, precaution should also be taken to prevent prawns from escaping through the water inlet and outlet of the paddies. In this experiment, screens were placed at the outlets of the paddies and these were constantly checked and cleaned to minimize escapes through cracks or overflows.

$M$. rosenbergii productivities obtained in the present experiment were lower than those reported by Asaduzzaman et al. (2006) and Ahmed et al. (2010) in Bangladesh, which were 412 and $467 \mathrm{~kg} \mathrm{ha}^{-1}$, respectively. However, they are similar to those observed for riceprawn simultaneous integrated systems by Giap et al. (2005) in Thailand (from 234 to $347 \mathrm{~kg} \mathrm{ha}^{-1}$ ); Lan et al. (2006) (194 to $373 \mathrm{~kg} \mathrm{ha}^{-1}$ ) and Phuong et al. (2006), in Vietnam (from 40 to $500 \mathrm{~kg} \mathrm{ha}^{-1}$ ) and Wahab et al. (2008) in Bangladesh (222 to $388 \mathrm{~kg} \mathrm{ha}^{-1}$ ). The lack of significant differences for yield in the treatments with and without feed may indicate that, under conditions in which the experiment was conducted, the system has enough natural food for prawn production at low densities (up to $5 \mathrm{~m}^{-2}$ ).

$M$. rosenbergii monocultures have a higher percentage of animals larger than $30 \mathrm{~g}$ compared to the present experiment, because the cultivation time normally is longer and, consequently, the final weight is bigger. However, the distributions of weight classes observed in this experiment are similar to those reported by Hai et al. (2001); Giap et al. (2005) and Lan et al. (2006) for integrated systems.

After sexual maturation, $M$. rosenbergii has different male morphotypes (Ra'anan and Cohen, 1982). In the present study, morphotype distribution was similar among all treatments, indicating no influence of density and feeding regime on the population structure. The greater number of small males (morphotype SM) and immature females and the lower number of ovigerous females and dominant males (morphotype BC) indicate low development of population. It may be due to a short growing cycle, characteristic of simultaneous integrated systems, which did not allow complete sexual maturation of the entire population. Similar results (30-34\% SM males and 44$46 \%$ virgin females) were reported by Mohanty (2010) in a simultaneous integrated system (rice-fish-prawn) after 4 months of culture. Nevertheless, in the present study, approximately $90 \%$ of prawns reached sizes over $15 \mathrm{~g}$, that can be considered adequate for selling in the Brazilian market. Thus, this short rearing cycle may be advantageous, since the prawns did not spend much energy with reproduction.

In Brazil, the selling price of rice frequently oscillates and thus rice monoculture often becomes unfeasible. It was also observed in the present study, but even in this situation, the rice-prawn integrated system was economically feasible. The IRR obtained was $6.4 \%$, a value very close to the MARR, which was $6.9 \%$. The $\mathrm{B} / \mathrm{C}$ was attractive because even with the low price paid for the $50-\mathrm{kg}$ bag of rice, each dollar invested in the rice-prawn culture generates US\$ 0.91 of revenue. The introduction of a high economic value species, as $M$. rosenbergii, in rice monoculture can allow the economic feasibility of rice production on a small scale, as observed in Southeast Asia by various authors (Kurup and Ranjeet, 2002; Mohanty et al., 2004; Giap et al., 2005; Phuong et al., 2006) and keeping the smallholders in the countryside.

In the present study, no pesticides were used. Future studies need to be conducted to determine the possibility of using pesticides that are common in rice culture, especially pre-emergent herbicides and biological insecticides. Meanwhile, despite some yield decrease due to the rice plagues, farmers can sell the rice as an organic or a "without-pesticide" product, getting better prices and consequently, increasing the profits. Currently, there are thousands of hectares of organic rice farms in Brazil, which do not use any pesticide and this opportunity can be exploited.

\section{Conclusions}

The rice-prawn simultaneous culture is technically feasible in southeastern Brazil and does not require supplemental diet at densities up to 5 prawns $\mathrm{m}^{-2}$ for the animals to reach commercial size. Nevertheless, the system is vulnerable to fluctuations of water temperature and predation, generating variation in prawn productivity and survival. The addition of prawns did not cause significant changes on the water quality and effluents.

The rice-prawn simultaneous culture at a stocking density of 2 prawns $\mathrm{m}^{-2}$ without commercial diets is economically feasible, which can compensate for the low rice prices. Nevertheless, the use of stocking densities as high as 5 prawns $\mathrm{m}^{-2}$ is not cost-effective due to the increase in prawn mortality and the expenditure with post larvae acquisition.

\section{Acknowledgments}

This study was partially funded by the financial resources of $\mathrm{CNPq}$ (472059/2009) and FAPESP (2006/56061-4).

\section{References}

Ahmed, N., Allison, E.H., Muir, J.F., 2010. Rice fields to prawns farms: a blue revolution in southwest Bangladesh? Aquac. Int. 18, 555-574. http://dx.doi.org/10.1007/s10499009-9276-0.

Ahmed, N., Bunting, S.W., Rahman, S., Gsrforth, C.J., 2013. Community-based climate change adaptation strategies for integrated prawn-fish-rice farming in Bangladesh to promote social-ecological resilience. Rev. Aquac. 5, 1-16. http://dx.doi.org/ 10.1111/raq.12022.

Amin, A.K.M., Salauddin, M., 2008. Effect of inclusion of prawn and mola on water quality and rice production in prawn-fish-rice culture system. Turk. J. Fish. Aquat. Sci. 8, $15-23$.

APHA, 2005. Standard methods for the examination of water and wastewater. 20th ed American Public Health Association, American Water Works Association, and Water Pollution Control Federation, Washington, DC.

Asaduzzaman, M., Wahab, M.A., Yi, Y., Diana, J.S., 2006. Bangladesh prawn-farming survey reports industry evolution. Glob. Aquac. Advocate 9, 41-43.

Boyd, C., Zimmermann, S., 2010. Grow-out systems - water quality and soil management. In: New, M.B., Valenti, W.C., Tidwell, J.H., D'Abramo, L.R., Kutty, M.N. (Eds.), Freshwater Prawns: Biology and Farming. Wiley-Blackwell, Oxford, England, pp. 239-254. 
D'Abramo, L.R., Sheen, S.S., 1994. Nutritional requirements, feed formulation and feeding practices for intensive culture of the freshwater prawn Macrobrachium rosenbergii. Rev. Fish. Sci. 2, 1-21.

Duong, L.T., 2001. Rice-prawn culture in the Mekong Delta of Viet Nam. FAO Fisheries Technical Paper No. 407, Integrated Agriculture-Aquaculture - A Primer. FAO (Food and Agriculture Organization of The United Nations), Roma (available at, http:// www.fao.org/docrep/005/Y1187E/y1187e22.htm\#z).

FAO, 2011. Save and Grow. A Policymaker's Guide to the Sustainable Intensification of Smallholder Crop Production. (Rome, 102 pp., available at www.fao.org).

FAO, 2013a. The State of Food and Agriculture. (Rome, 99 pp., available at, www.fao.org)

FAO, 2013b. FAOSTAT Statistical Database available at, faostat.fao.org.

Forés, E., Comín, F.A., 1992. Ricefields, a limnological perspective. Limnetica 10, 101-109.

Frei, M., Razzak, M.A., Hossain, M.M., Oehme, M., Dewan, S., Becker, K., 2007. Methane emissions and related physicochemical soil and water parameters in rice-fish systems in Bangladesh. Agric. Ecosyst. Environ. 120, 391-398. http://dx.doi.org/ 10.1016/j.agee.2006.10.013

Giap, D.H., Yi, Y., Lin, C.K., 2005. Effects of different fertilization and feeding regimes on the production of integrated farming of rice and prawn Macrobrachium rosenbergii (De Man). Aquac. Res. 36, 292-299. http://dx.doi.org/10.1111/j.1365-2109.2005. 01244.x.

Hai, T.N., Hien, T.T.T., Tam, D.H., Toan, V.T., Phuong, N.T., Wider, M.N., 2001. Culture of freshwater prawn (Macrobrachium rosenbergii) in rice-fields using hatchery-reared postlarvae in Tam Binh District, Vinh Long Province, Vietnam. Proceedings of the 2001 Annual Workshop of JIRCAS Mekong Delta Project, pp. 159-166.

Henares, M.N.P., Camargo, A.F.M., Biúdes, J.F., 2011. Impacto da manutenção de reprodutores de Macrobrachium rosenbergii na qualidade da água. Bol. Inst. Pesca 37 (2), 183-190.

Hung, L.T., 2001. Rice-prawn and rice-prawn culture in coastal areas of Viet Nam. FAO Fisheries Technical Paper No. 407, Integrated Agriculture-Aquaculture - A Primer. FAO (Food and Agriculture Organization of The United Nations), Roma (available at http://www.fao.org/docrep/005/Y1187E/y1187e23.htm\#aa).

Jolly, C.M., Clonts, H.A., 1993. Economics of Aquaculture. Food Products Press, New York (319 pp.).

Keppeler, E.C., Valenti, W.C., 2006. Effects of selective harvest of the Amazon River prawn, Macrobrachium amazonicum on pond water, sediment and effluent. Acta Limnol. Bras. 18 (2), 109-119.

Kimpara, J.M., Rosa, F.R.T., Preto, B.L., Valenti, W.C., 2011. Limnology of Macrobrachium amazonicum grow-out ponds subject to high inflow of nutrient-rich water and different stocking and harvest management. Aquac. Res. 42, 1289-1297.

Kunda, M., Azim, M.E., Wahab, A.M., Dewan, S., Roos, N., Thilsted, S.H., 2008. Potential of mixed culture of freshwater prawn (Macrobrachium rosenbergii) and self-recruiting small species mola (Amblypharyngodon mola) in rotational rice-fish/prawn culture systems in Bangladesh. Aquac. Res. 39 (5), 506-517. http://dx.doi.org/10.1111/j. 1365-2109.2008.01905.x

Kuris, A.M., Ra'Anan, Z., Sagi, A., Cohen, D., 1987. Morphotypic differentiation of male Malaysian giant prawns, Macrobrachium rosenbergii. J. Crustac. Biol. 7 (2), 219-237.

Kurup, B.M., Ranjeet, K., 2002. Integration of freshwater prawn culture with rice farming in Kuttanad, India. Naga WorldFish Cent. Q. 25 (3-4), 16-19.

Lan, M.L., Long, D.N., Micha, J.C., 2006. The effects of densities and feed types on the production of Macrobrachium rosenbergii (De Man) in the rotational rice-prawn system. Aquac. Res. 37, 1297-1304. http://dx.doi.org/10.1111/j.1365-2109.2006.01562.x.
Mishra, A., Mohanty, R.K., 2004. Productivity enhancement through rice-fish farming using a two-stage rainwater conservation technique. Agric. Water Manag. 67, 119-131. http://dx.doi.org/10.1016/j.agwat.2004.02.003.

Mohanty, R.K., 2010. Impact of phased harvesting on population structure, feed intake pattern and growth performance of Macrobrachium rosenbergii De Man (giant freshwater prawn) in polyculture with carps in concurrent rice-fish culture. Aquac. Int. 18, 523-537. http://dx.doi.org/10.1007/s10499-009-9263-5.

Mohanty, R.K. Jena, S.K., Thakur, A.K., Patil, D.U., 2009. Impact of high-density stocking and selective harvesting on yield and water productivity of deepwater rice-fish systems. Agric. Water Manag. 96, 1844-1850. http://dx.doi.org/10.1016/j.agwat.2009.08.006.

Mohanty, R.K., Thakur, A.K., Ghosh, S., Mohanty, S., Patil, D.U., 2010. Performance evaluation of concurrent rice-fish-prawn culture with and without cull harvesting. Aquac. Res. 41, 1402-1412. http://dx.doi.org/10.1111/j.1365-2109.2009.02432.x.

Mohanty, R.K., Verma, H.N., Brahmanand, P.S., 2004. Performance evaluation of rice-fish integration system in rainfed medium land ecosystem. Aquaculture 230, 125-135. http://dx.doi.org/10.1111/j.1365-2109.2009.02432.x.

Nahar, A., 2010. Impacts of different rice-fish-prawn culture systems on yield of rice, fish and prawn and limnological conditions. J. Bangladesh Agric. Univ. 8 (1), 179-185. http://dx.doi.org/10.3329/jbau.v8i1.6416.

Phuong, N.T., Hai, T.N., Hien, T.T.T., Bui, T.V., Huong, D.T.T., Son, V.N., Morooka, Y., Fukuda, Y., Wilder, M., 2006. Current status of freshwater prawn culture in Vietnam and the development and transfer of seed production technology. Fish. Sci. 72, 1-12. http:// dx.doi.org/10.1111/j.1444-2906.2006.01109.x.

Ra'Anan, Z., Cohen, D., 1982. Production of the freshwater prawn, Macrobrachium rosenbergii, in Israel. Winter activities 1980/81. Bamidgeh 34, 47-58.

Shang, Y.C., 1990. Aquaculture Economic Analysis: An Introduction. The World Aquaculture Society, Baton Rouge (211 pp.).

Sokal, R.R., Rohlf, F.J., 1995. Biometry. $3^{\text {a }}$ ed. Freeman, New York (87 pp.).

Tidwell, J.H., Coyle, S.D., Webster, C.D., Sedlacek, J.D., Weston, P.A., Knight, W.L., Hill, S.J., D'Abramo, L.R., Daniels, W.H., Fuller, M.J., 1997. Relative prawn production and benthic macroinvertebrate densities in unfed, organically fertilised, and fed pond systems. Aquaculture 149, 227-242.

USEPA - United States Environmental Protection Agency, 2000. Manual for constructed wetlands treatment of municipal wastewaters. EPA/625/R-99/010 (Cincinnati, 166 pp.).

Valenti, W.C. New, M.B., Salin, K.R., Ye, J, 2010. Grow-out systems - monoculture. In: New, M.B., Valenti, W.C., Tidwell, J.H., D'Abramo, L.R., Kutty, M.N. (Eds.), Freshwater Prawns: Biology and Farming. Wiley-Blackwell, Oxford, England, pp. 154-179.

Wahab, M.A., Kunda, M., Azim, M.E., Dewan, S., Thilsted, S.H., 2008. Evaluation of freshwater prawn-small fish culture concurrently with rice in Bangladesh. Aquac. Res. 39, 1524-1532. http://dx.doi.org/10.1111/j.1365-2109.2008.02025.x.

Williams, D., Reshad, A., Francisco, N., 2004. Integrated rice/fish/prawn system in Bangladesh. Paper Presented at the International Conference on "Sustainable Aquatic Resources are More than Managing Fish" The Eco-system Approach in Inland Fisheries and Role of Intra-country Linkages. Penag, Malaysia, January 12-16, 2004 (available at, http://www.gnaec.org/pdf).

Zar, J.H., 1999. Biostatistical Analysis. Prentice Hall, Englewood Cliffs, New Jersey, USA.

Zimmermann, S., Nair, C.M., New, M.B., 2010. Grow-out systems - polyculture and integrated culture. In: New, M.B., Valenti, W.C., Tidwell, J.H., D'Abramo, L.R., Kutty, M.N. (Eds.), Freshwater Prawns: Biology and Farming. Wiley-Blackwell, Oxford, England, pp. 195-217. 